\title{
親水/疎水基板へのメゾポーラスシリカ膜の成長
}

\author{
杉村博之*，穂積 篤*，牛山和哉*，高井 治*，興戸正純**
}

\section{Growth of Mesoporous Silica Films on Hydrophilic or Hydrophobic Surfaces}

\author{
Hiroyuki SUGIMURA*, Atsushi HOZUMI*, Kazuya USHIYAMA*, Osamu TAKAI* \\ and Masazumi OKIDO**
}

\begin{abstract}
Key Words : Mesoporous Silica, Organosilane Self-Assembled Monolayer, Molecular Recognition, Photolithography, Biomimetic Materials Processing
\end{abstract}

\section{1. 緒言}

両親媒性有機分子はある濃度範囲で，棒状ミセルが数 $\mathrm{nm}$ 以下の間隔で整列した六方晶相リオトロピック液晶 ミセルを形成する。この液晶ミセルをテンプレートに用 いて, ナノ細孔がへキサゴナル配置で規則的に並んでい る六方晶多孔質酸化シリコン(メゾポーラスシリカ, MPS)を作製することができる1),2)。この MPSをグラ ファイトや雲母の䢃開面上へ堆積させると, 配向性のそ ろった膜ができることが知られている ${ }^{3), 4)}$

本論文では，MPS膜の微細構造制御を目的とし，ま ず基板の親水性／疎水性がどのような影響を与えるか調 べた結果について報告する。

\section{2. 実験}

実験には 3 種類の基板を用いた。ひとつは, 紫外線一 オゾン洗浄によって，水滴接触角がほぼ 0 度になるまで 親水化したシリコン単結晶(100 面)基板である。疎水性 基板は, 光洗浄したシリコン基板上に, 有機シラン単 分子膜を被覆することによって作製した（水滴接触 角 100 度強）。原料に octadecyltrimethoxylsilane $\left(\mathrm{C}_{18} \mathrm{H}_{37} \mathrm{Si}\left(\mathrm{OCH}_{3}\right)_{3}\right)$ を用い, 気相法によって被覆した ${ }^{5)}$ 。 上記の疎水性有機シラン単分子膜被覆基板に, フォトマ スク越しにエキシマランプ光(波長 $172 \mathrm{~nm}$, ウシオ電機, UEM 20-172)を照射しパターニングしたものを第 3 の 基板として用いた。光照射された領域では単分子膜が光 酸化によって分解・除去され，親水性の酸化シリコン表 面が露出している6)。

*名古屋大学大学院 工学研究科（T464-8603 愛知県名古屋 市千種区不老町)

Graduate School of Eng., Nagoya Univ. (Furo-cho, Chikusa-ku, Nagoya-shi, Aichi 464-8603)

**名古屋大学 理工学総合研究センター(T464-8603 愛知県 名古屋市千種区不老町)

Center for Integrated Research in Sci. and Eng., Nagoya Univ. (Furo-cho, Chikusa-ku, Nagoya-shi, Aichi 4648603)
これら 3 種類の基板上に, cetyltrimethylammoniumchroride (CTA: $\left.\mathrm{H}_{3} \mathrm{C}\left(\mathrm{CH}_{2}\right) 15 \mathrm{~N}+\left(\mathrm{CH}_{3}\right)_{3} \mathrm{Cl}^{-}\right)$, 塩 酸 $(\mathrm{HCl})$, tetraethoxysilane (TEOS: $\left.\mathrm{Si}\left(\mathrm{OC}_{2} \mathrm{H}_{5}\right)_{4}\right)$ の 混 合水溶液から, MPS 膜を堆積させた。反応溶液のモル 比は, $\mathrm{H}_{2} \mathrm{O}: \mathrm{HCl}$ : CTA : TEOS $=100: 7: 0.11$ ： 0.1 とした。基板を液面上に浮かべ, 溶液をかくはんせ ず静止したままで室温で 5 時間反応させた。反応後, 基 板を取り出して純水で洗浄し乾燥させた。取り出した基 板を，赤外吸収分光(バイオラッド，FTS-175 C), X線 回折 (理学電機, RINT 2200), 原子間力顕微鏡 (AFM : arc Scientific Instruments, Autoprobe-LS), 光学顕微鏡 (ニコン, Optiphoto $100 \mathrm{~S}$ )によって評価し た。

\section{3. 結果および考察}

酸性水溶液中で TEOS 分子は加水分解され, $\mathrm{Si}\left(\mathrm{O}^{-}\right)_{4}$, となる。一方，力チオン性界面活性㓮である CTA は, 親水性の $\mathrm{N}^{+}$外側へ向けたミセルを形成する。した がって, $\mathrm{Si}\left(\mathrm{O}^{-}\right)_{4}$ イオンは，正に帯電したミセル表面へ 集合し，ミセルを包むように重合膜を形成する。図 $1 \mathrm{a}$, $\mathrm{b}$ に, 親水性基板, 疎水性基板上に堆積したMPS の赤 外吸収スペクトルを示す。シリコン基板では全く見られ ない C-H 結合による吸収が，MPS膜では 2800〜2900 $\mathrm{cm}^{-1}$ 付近に存在する(図 $1 \mathrm{a}$ )。また, 酸化シリコンに
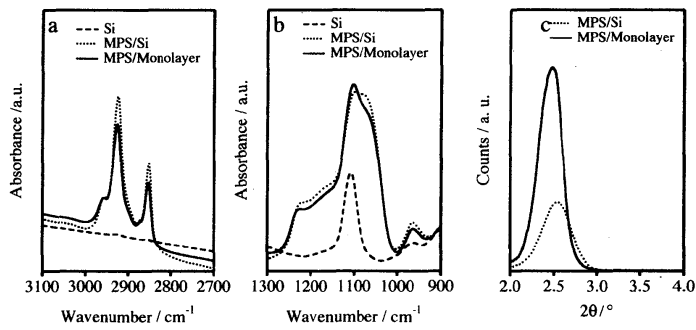

Fig. 1 IR absorption spectra ( $\mathrm{a}$ and $\mathrm{b}$ ) and X-ray diffraction patterns (c) of MPS films. 

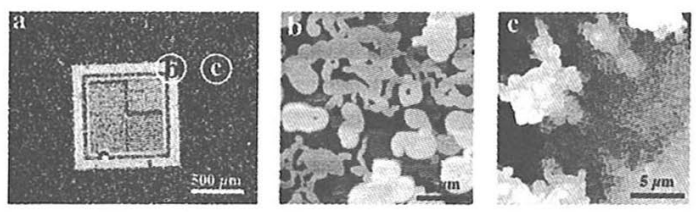

Fig. 2 Surface morphology of a MPS film deposited on a photopatterned ODS monolayer.

a : Dark-field optical microscope photograph, b : AFM image the MPS film on the hydrophobic region, $c$ : AFM image the MPS film on the hydrophilic region.

由来する吸収ピークが，1000〜 $1200 \mathrm{~cm}^{-1}$ 付近にみられ る(図 1 b)。シリコン自然酸化膜の吸収ピークと比べる と,ブロードでいくつかの成分からなっている。完全に 加水分解していない TEOS に由来する Si-O-C 結合によ る吸収が含まれているものと考えられる。

図 $1 \mathrm{c}$ に, MPS 膜のX線回折図形を示す。どちらの 基板でも, $2 \theta \doteqdot 2.5^{\circ}$ に回折ピークが見られた。繰り返 し長約 $3.5 \mathrm{~nm}$ の周期構造が，基板と平行な面内にある ことを示している。回折ピーク強度を見ると, 疎水性基 板のほうが約 3 倍回折ピーク強度が大きい。赤外吸収の 結果は, どちらの基板にもほ浪同量の堆積物が存在する ことを示しており, 回折ピーク強度の違いは, 疎水基板 上の方が，MPS の細孔の軸が基板と平行に配向してい る度合いが大きいからである。

光パターニングした基板上の MPS 膜の光学顕微鏡写 真(暗視野像)を図 2 aに示す。明るく見える部分が, 光照射によって視水化された領域である。暗視野影微鏡 では散乱光を結像させるため，凹凸の多い場所の方が明 るく観察される。したがって, 親水性領域に堆積した MPS の方が, 疎水性領域に堆櫝した MPSより凹凸が 大きいことになる。それそれれの領域(図 $2 a$ に示した b, cの領域)を, AFMにより観察した結果からも, そのこ とがわかる(図 $2 \mathrm{~b}, c$ )。親水性領域に成長した MPS 膜 (図 $2 \mathrm{~b}$ ) の表面は, 直径 2 $4 \mu \mathrm{m}$ の円盤状の堆積物 と, 幅 1 2 $\mu \mathrm{m}$ の紐状の堆積物で覆われている。塩酸 酸性中で合成されたMPSで典型的に見られる形状であ る2)。疎水性基板上に成長したMPS膜は，大きなうね りはあるが, 比較的平坦な表面をしている。

踈水性基板表面でカチオン性界面活性剤分子は, 界面 活性剂分子のアルキル鎖と基板表面分子とが疎水性相互 作用により集合し，棒状ミセルを繸に半分に断ち割って 基板上に伏せた形状の半ミセルが基板上に配列している

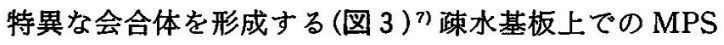
成長でには，この界面分子会合体の構造に做うょうに棒 状ミセルがへキサゴナルに配置した液晶が形成される。 その結果, 堆積するMPS 膜の細孔は基板表面に平行に 配向することになる。一方, 親水性基板の表面は, 酸化

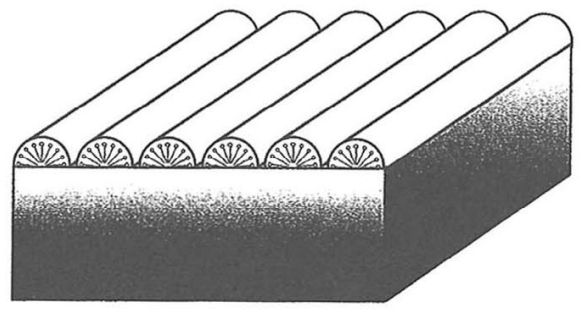

Fig. 3 A half-cylindrical micellar array formed on a hydrophobic substrate.

シリコンでおおわれているため, 图 3 のような界面ミセ ルは形成されない。漞水基板上のMPS膜が，液相中で 成長し沈殿したMPS と同じ形状2であったことから考 えて，液中で形成された微小 MPS クラスターが基板表 面に吸着しそれを核として成長したのではないかと考 えられる。

\section{4. 結 論}

MPS 膜を親水性基板・疎水性基板に成長させ，その 結晶構造および表面モルフォロジーを観察した。疎水性 基板表面でのMPS成長においては，単分子膜と界面活 性剤分子間の疎水性相互作用によって界面活性剤分子が 特異的に配向し MPS 結晶の㥢向成長を促した。この場 合, 有機シラン単分子膜は, 一種の分子認識機能を発揮 したと考えることができる。フォトリソグラフィによっ て基板上に親水/疎水性からなる微細パターンを形成し ておくことによって，MPS莫の配向・モルフォロジー を局所的に制御することができた。有機シラン分子とリ ソグラフィによる微細パターン化を組み合わせれば, 基 板表面の分子配列と幾何学的微細構造を両方とも制御で き,より高度な結晶成長制御・微細構造制御が可能にな る。

本研究は, 名古屋大学・理工科学総合研究センターの 学際共同研究プログラムによって行われた。

(Received December 11, 1998 ; Accepted April 14, 1999)

\section{文献}

1) C. T. Kresge, M. E. Leonowicz, W. J. Roth, J. C. Vartuli and J.S. Beck ; Nature, 359, 710 (1992)

2) H. Yang, N. Coombs and G. A. Ozin : Science, 386, 692 (1997)

3) H. Yang, N. Cooms, I. Sokolov and G. A. Ozin ; J. Mater. Chem., 7, 1285 (1997)

4) H. Yang, A. Kuperman, N. Cooms, S. Mamiche-Afara and G. A. Ozin : Nature, 379, 703 (1996)

5 ) H. Sugimura and N. Nakagiri : J. Photopolym. Sci. Technol., 10, 661 (1997)

6) H. Sugimura and N. Nakagiri : Appl. Phys. A, 66, S 427 (1998)

7) S. Manne and H. E. Gaub ; Science, 270, 1480 (1995) 